\title{
PREPARATION OF MONOCLONAL ANTIBODIES AGAINST INFECTIOUS LARYNGOTRACHEITIS VIRUS (ILT)
}

\author{
YOUSSEF M. M., HANAN M. ELZAHED, AMAL EL SAWAH \\ and ELHAM A. ELEBIARY
}

Central Laboratory For Evaluation Of Veterinary Biologics (CLEVB), ARC, Dokki, Giza, Egypt

(Manuscript received 29 April 2014)

\begin{abstract}
$\mathrm{H}$ ybridomas which secrete monoclonal antibodies (MAbs) against Infectious laryngotracheitis virus (ILTV) were produced. The hybrid cells resulted from fusion of P3X63Ag8.653 myeloma cells with splenocytes of Balb/c mice which had been immunized with purified ILTV. After immunization the humoral immune response to immunizations was assessed by ELISA using purified ILTV as the target. Screening of supernatant fluids after cell fusion was performed by an indirect enzyme-linked immunosorbent assay (ELISA). The results indicated that the obtained (MAbs) against ILTV were of high specificity and with ambient concentration that would be useful as a tool for diagnosis and identification of ILT virus.

Keywords: (MAbs / ILTV / antibody production/ Hybridoma Technology/ ELISA).
\end{abstract}

\section{INTRODUCTION}

Infectious laryngotracheitis virus (ILTV) had been selected in the current research as a model to start with in our ambitious future plan to produce and have panels of monoclonal antibodies for all viral and bacterial agents included in the biologics subjected for quality control at the Central Laboratory for Evaluation of Veterinary Biologics (CLEVB).

Infectious laryngotracheitis virus (ILTV) is a member of the Herpesviridae, the genus Iltovirus and Gallid herpesvirus1 species. It is an important respiratory disease and causes significant economic losses in the poultry industry world-wide (Shan and Joseph 2012). Sources of transmission of ILT infection are three-fold, namely: chickens with acute upper respiratory tract disease, latently infected 'carrier' fowls which excrete infectious laryngotracheitis virus (ILTV) when stressed, and all fomites (inanimate articles as well as the personnel in contact with infected chickens. The disease is mainly controlled through biosecurity and by vaccination with liveattenuated vaccines. Currently, there are two main types of ILTV live vaccines commercially available, those attenuated by sequential passages in chicken embryo origine (CEO) or by sequential passages in tissue culture origine (TCO). Attenuated vaccines, particularly those derived by passage in chicken embryos, have been 
associated with a number of side effects, including residual virulence, transmission to naive birds, establishment of latent infections with subsequent reactivation and shedding of virus.

A new generation of viral vector fowl poxvirus (FPV) and herpesvirus of turkey (HVT) vaccines carrying ILTV gene has been developed and such vaccines are commercially available (Johnson et. al., 2010).

ILTV-specific MAbs can be used for antigen detection in the tracheas of infected chickens by indirect immunofluorescence, immunoperoxidase tests, or by enzyme-linked immunosorbent assay (ELISA) (Guy et. al., 1992, Abbas et. al., 1996) where all of them are helpful tools for diagnosis of ILT.

ILTV-specific monoclonal antibodies (MAbs) have already been used to establish an ELISA for antigen detection. The use of the MAbs could facilitate standardization of serologic tests and help to reduce the high background levels that are frequently caused by nonspecific reactions of chicken antisera in conventional direct ELISAs (Meulemans and Halen 1982). Therefore, we have planned to produce an additional set of ILTV-specific MAbs, attempt to identify their viral target. However the main aim and the real objective of our present study is to establish the technology of monoclonal antibodies in CLEVB.

\section{MATERIALS AND METHODS}

\section{- ILT virus}

Infectious laryngotracheitis virus strain (CHP50) of commercial live ILT vaccine included in this study was provided by Strains Bank Department, Central laboratory for Evaluation of Veterinary Biologics (CLEVB), Agriculture Research Center (ARC), Egypt.

\section{- ILT Virus Antigen}

The ILTV antigen was prepared essentially according to the methods described by (Izuchi et. al. 1982). The concentration and purification procedures used for the ILT virus strain were done according to the protocol reported by Stoschek (1990).

\section{Mouse immunization}

Five female BALB/c mice were immunized intraperitoneally with an emulsion containing live virus and Freund's complete adjuvant. About $1 \mathrm{ml}$ of pure virus was emulsified with $1 \mathrm{ml}$ of Freund's complete adjuvant. About $0.2 \mathrm{ml}$ of this virus was injected intraperitoneally to each mouse. Three weeks later, mice were immunized through the same route with an emulsion containing purified virus and incomplete Freund's adjuvant. The immune response to the ILTV virus was assessed by 
measuring the titer of polyclonal antibody in mouse serum using ILT virus IDEXX Laboratories kit. An intravenous booster injection of $1 \mathrm{ml}$ of the purified virus without any adjuvant was given to the mice 4 days before fusion (Kohler and Milstein, 1975). Five unimmunized female BALB/c mice were also kept for a source of negative control serum.

\section{Cell lines and medium}

The Myeloma cell line P3 X63Ag8.653 was obtained from the Monoclonal Antibody Production Unit (MAPU) and kindly provided by Professor Rafik Soliman, Faculty of Veterinary Medicine, Cairo University. Myeloma cell line P3 X63Ag8.653 was grown in RPMI1640 medium supplemented with $15 \%$ fetal bovine serum. $1 \mathrm{mM}$ pyruvate, $1 \mathrm{mM}$ L-glutamine (glutamine added weekly), and $1 \% 100 \mathrm{X}$ Pen/ Strep (medium and all reagents were supplied by Gibco, Grand Island, NY 14072). All myelomas and hybridomas were grown at $370 \mathrm{C}$ in an atmosphere of $7 \% \mathrm{CO} 2$. Suspensions of rapidly growing myeloma cells $(<10 \mathrm{~s} / \mathrm{ml})$ were diluted with equal volumes of fresh medium daily for 3 days prior to fusion to ensure that the cells were in optimum condition for fusion (Nowinski et. al., 1979).

\section{Feeder cells and conditioned media}

Peritoneal macrophages were prepared from euthionized adult BALB/c mice. Abdominal skin was removed to expose the peritoneal wall. The wall was bathed in $70 \%$ ethanol, and 4-5 $\mathrm{ml}$ of $0.34 \mathrm{M}$ stock sucrose solution was injected through a (18gauge) needle into the peritoneal cavity (care was taken to avoid puncture of the gut). After a gentle massage of the abdomen, the sucrose macrophage solution was withdrawn. Macrophage cells were washed twice in serum-free medium, resuspended in complete medium at $10^{5} \mathrm{ml}^{-1}$, and dispensed $(0.1 \mathrm{ml}$ per well) into 96-well tissue culture plates. Spleen cell-conditioned medium was made by dispersing the cells of one BALB/c mouse spleen into $100 \mathrm{ml}$ of complete media in a $75 \mathrm{~cm}^{2}$ tissue culture flask and incubating at $37^{\circ} \mathrm{C}$ for $24 \mathrm{hr}$. The medium was used within 3 days of preparation.

\section{Cell fusion}

Cell fusions were done with polyethylene glycol (PEG) procedures (Galfre et. al., 1977 and Nowinski et. al. 1979). Spleen cells were gently dispersed by repeatedly injecting the spleen with serum-free RPMI 1640 (incomplete medium) through a (20gauge) needle. Spleen cells $\left(10^{8}\right)$ and myeloma cells $\left(10^{7}\right)$ were washed three times in $40 \mathrm{ml}$ of incomplete medium by centrifugation at $160 \mathrm{~g}$ for $10 \mathrm{~min}$. Spleen and myeloma cells were combined at a 10:1 ratio and pelleted at $160 \mathrm{~g}$ for $10 \mathrm{~min}$. The supernatant was aspirated, and the pellet was gently resuspended with $1.5 \mathrm{ml}$ of $40 \%$ 
(w/v) PEG 4000 (Sigma) in serum-free medium added dropwise over a period of 45 sec. The mixture was incubated at $370 \mathrm{C}$ for $75 \mathrm{sec}$ with gentle shaking. The PEG solution was diluted by adding aliquants of 2,2 , and $20 \mathrm{ml}$ of complete medium dropwise over a period of $1 \mathrm{~min}$ for each aliquant with a 1-min incubation between aliquants. The cell suspension was centrifuged for $10 \mathrm{~min}$ at $160 \mathrm{~g}$. and the pellet was resuspended in complete medium supplemented with $10^{-4}$ hypoxanthine, $4 \times 10^{-7} \mathrm{M}$ aminopterin, and $1.6 \times 10^{-5} \mathrm{M}$ thymidine (HAT). The fusion product of the spleen was distributed into three 96-well tissue culture plates pre-seeded with $10^{4}$ peritoneal macrophages in $0.1 \mathrm{ml}$ of complete medium. HAT selective medium supports the growth of spleen-myeloma hybrid cells, but not unfused myeloma cells or myelomamyeloma cell hybrids (Hammerling et. al. 1981 and Kennett et. al. 1980) Hybridoma plates were examined for cell growth beginning 7 days after the fusion. Cells were fed by replacing $50 \%$ of the medium in each well on days $7,10,13$, and 16 with spleencell conditioned HAT medium, and on days 19, 22, 25, and 28 with spleen-cellconditioned HT medium (complete medium $+10^{-4}$ hypoxanthine $+1.6 \times 10^{-5} \mathrm{M}$ thymidine). Cells were fed every 3-4 days thereafter with complete medium. Hybridomas were screened for antibody production to the immunizing ILT virus beginning on day 14 . Positive hybridomas reaching $50 \%$ confluence in a well of a $96-$ well plate were transfered to $1-\mathrm{ml}$ cultures in a 24-well plate and were retested and then grown in mass culture.

\section{ELISA screening for Hybridomas}

At day 14 the wells were screened for choice of the desired Hybridomas producing antibodies specific for the injected ILT virus by indirect ELISA. Enzyme immunoassay (Nunc, Roskilde, Denmark) plates were coated with $100 \mu \mathrm{L}$ ILTV Ag per well at a concentration of $100 \mathrm{ng} / \mathrm{mL}$ in PBS buffer (pH:7.2) at $4^{\circ} \mathrm{C}$ overnight. The unspecific bindings were blocked with nonfat milk powder for $1 \mathrm{~h}$ at $37^{\circ} \mathrm{C}$ and washed 3 times with $0.05 \%(\mathrm{v} / \mathrm{v})$ PBS-tween-20 (PBST). The supernatant of hybridoma was incubated for $1 \mathrm{~h}$ at $37^{\circ} \mathrm{C}$, with mice serum as a positive control. Plates were then washed three times with PBST. The bound antibodies were detected with alkaline phosphatase conjugated goat anti-mouse serum (IgG) antibodies diluted 1/1000 in PBS buffer for $1 \mathrm{~h}$ at $37^{\circ} \mathrm{C}$. Finally, Paranitrophenyl phosphate $(1 \mathrm{mg} / \mathrm{mL}$ solution in substrate buffer) was added and the reaction was measured by the absorbance at 405 $\mathrm{nm}$ on a Bio-Tech enzyme immunoassay (ELISA) reader. Normal mouse serum and immune serum from the mice used for cell fusion were used in the assays for negative and positive controls at dilutions of 1:500-1:1,000. Cell culture medium from normal myeloma cells was used as a negative control for the hybridoma media. Positive wells were cloned by limiting dilution method using macrophages as feeder cells. 
standardized home-made ILTV ELISA Kit were used for all further hybridomas screenings with all proper required controls (culture media, positive and negative mouse serum, CAM suspension, hybridoma positive supernatants). also other poultry viral diseases ELISA kits were used to confirm unique specificity of the prepared monoclonal antibodies against ILTV.

\section{Cloning}

Several hybridoma cell lines were selected for further characterization. Positive selected wells were cultured in Hypoxanthine Thymidine (HT) (Sigma) medium for further two weeks and were passed two to three times at low cell densities, retested for antibody production, Hybridoma cell lines producing specific antibodies were cloned by limiting dilution calculated to give $<1$ cell/well (Anonymous, 1991). Then retested and re-cloned in spleen-cell-conditioned media to single cell clones by limiting dilution at least three times to ensure monoclonality and stability of the cell line. Cells were diluted to $20 \mathrm{ml}$ of suspension containing 30-50 viable cells and plated at $0.2 \mathrm{ml}$ per well into a 96-well plate. Single-cell clones were selected from plates in which $<35 \%$ of the wells contained hybridomas. Finally selected recloned hybridoma cells were adapted gradually to grow in lower serum medium and retested for the continuous production and secretion of specific monoclonal antibodies against (ILTV).

\section{RESULTS}

\section{Mouse immunization}

Sera of the immunized mice obtained from conjuntival venous sinuses showed a positive reaction against ILTV in indirect ELISA and their spleens were used for fusion. Serum from unimmunized mice did not show any reaction with ILTV in indirect ELISA.

\section{Cell fusion and hybridoma selection.}

The hybridomas in the form of growing small clumps of cells were observed starting by 7 days and after 10 days of fusion in 96-well plates. 11 Positive wells were identified and selected at day 14 after fusion by using their supernatant against ILTV in an indirect ELISA. 

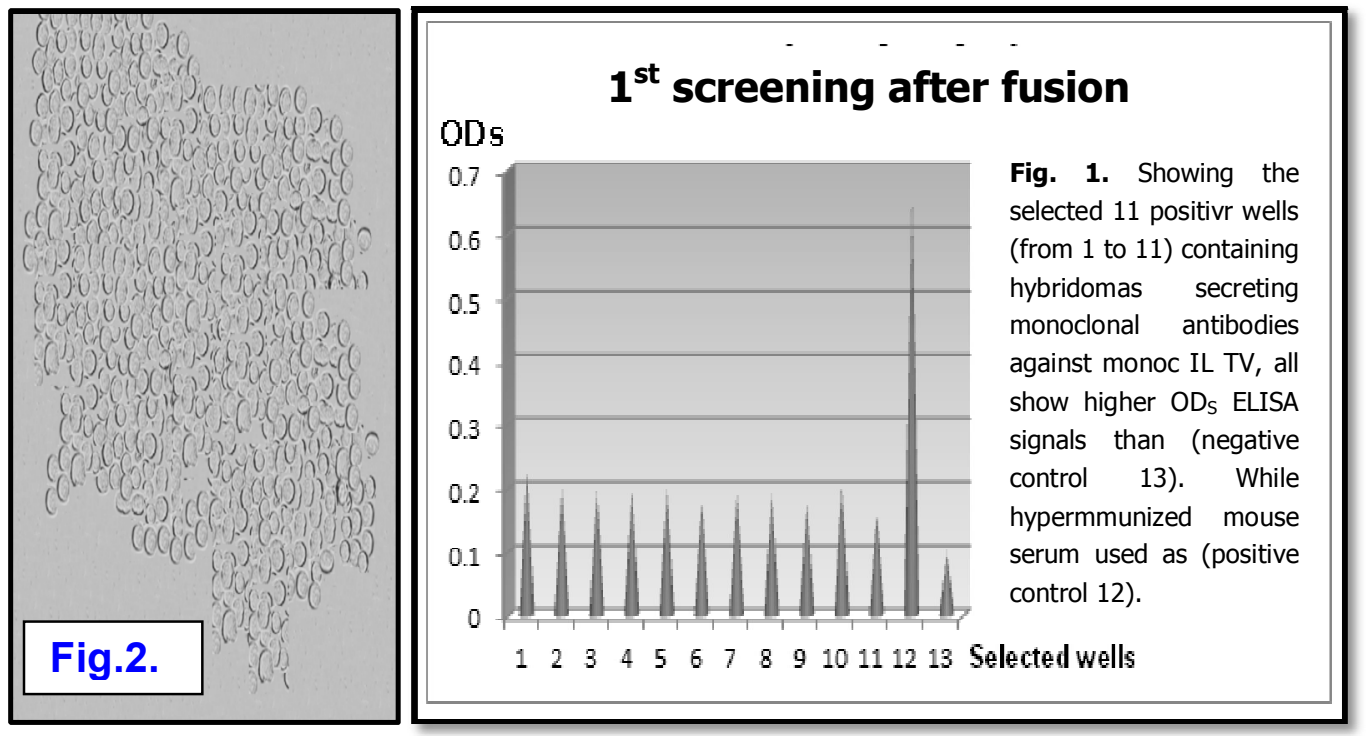

Fig.2. Hybridomas were screened for antibody production to the immunizing ILT virus beginning on day 14 . Positive hybridomas reaching $50 \%$ confluence in a well of a 96-well plate were transfered to 1 -ml cultures in a 24-well plate and were retested and then grown in mass culture.

\section{Cloning}

Thirity three hybridoma clones secreted monoclonal antibodies specific for ILTV were produced after cloning by limiting dilution of the 11 positive wells selected after 1st screening. (Fig.3). Five hybridomas of the 33 were further selected and subjected to three extra rounds of cloning cycles to prove monoclonality, specificity and stable productivity. All cloning results were shown within Figures from 5 to 12 . (Fig. 3, 4, 5, 6, 7, 8, 9 and 10). 


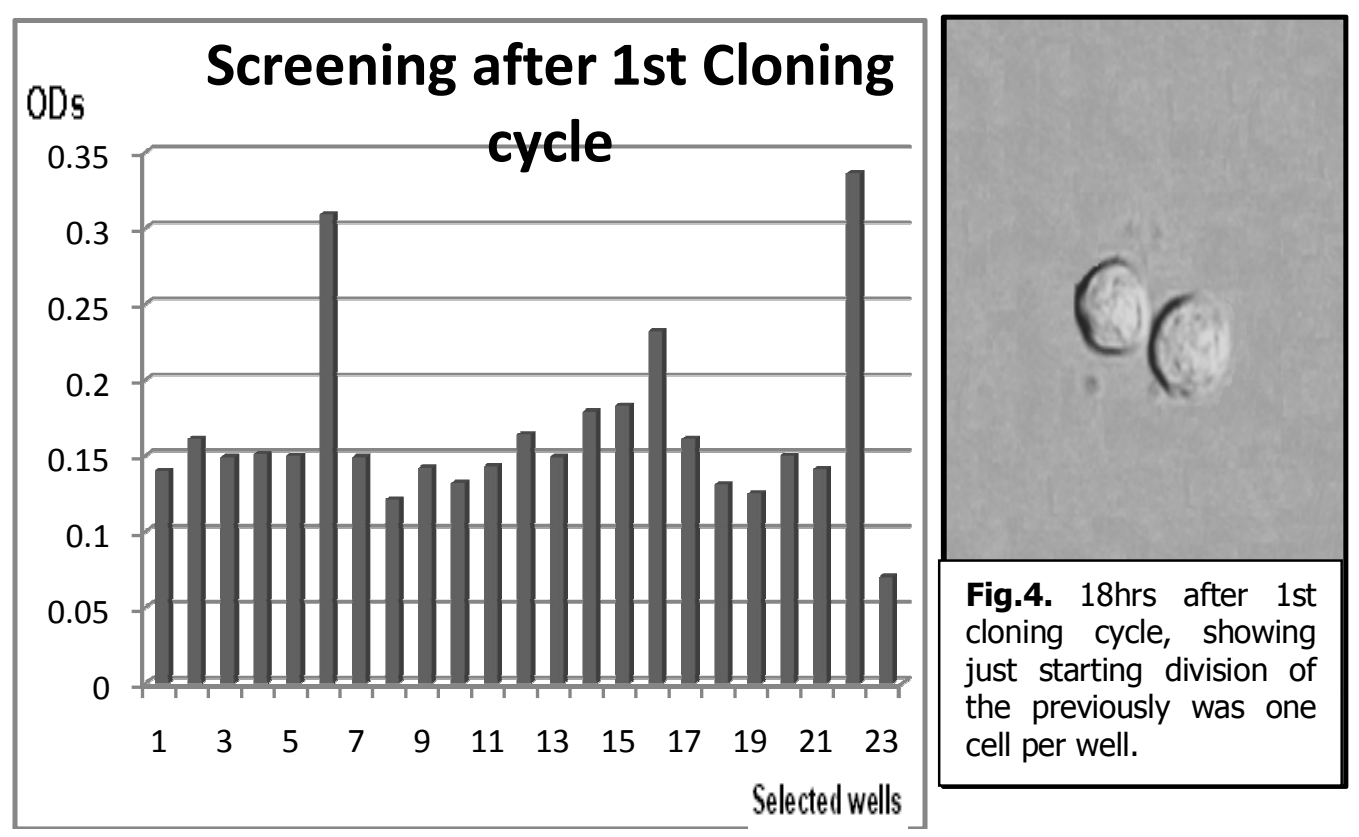

Fig. 3. Showing the selected 21 positive wells (from 1 to 21 ) containing hybridoma clones secreting monoclonal antibodies against ILTV, all show higher ODs. ELISA signals than culture media (negative control 23).While previously tested positive monoclonal antibodies against ILTV used as (positive control 22).
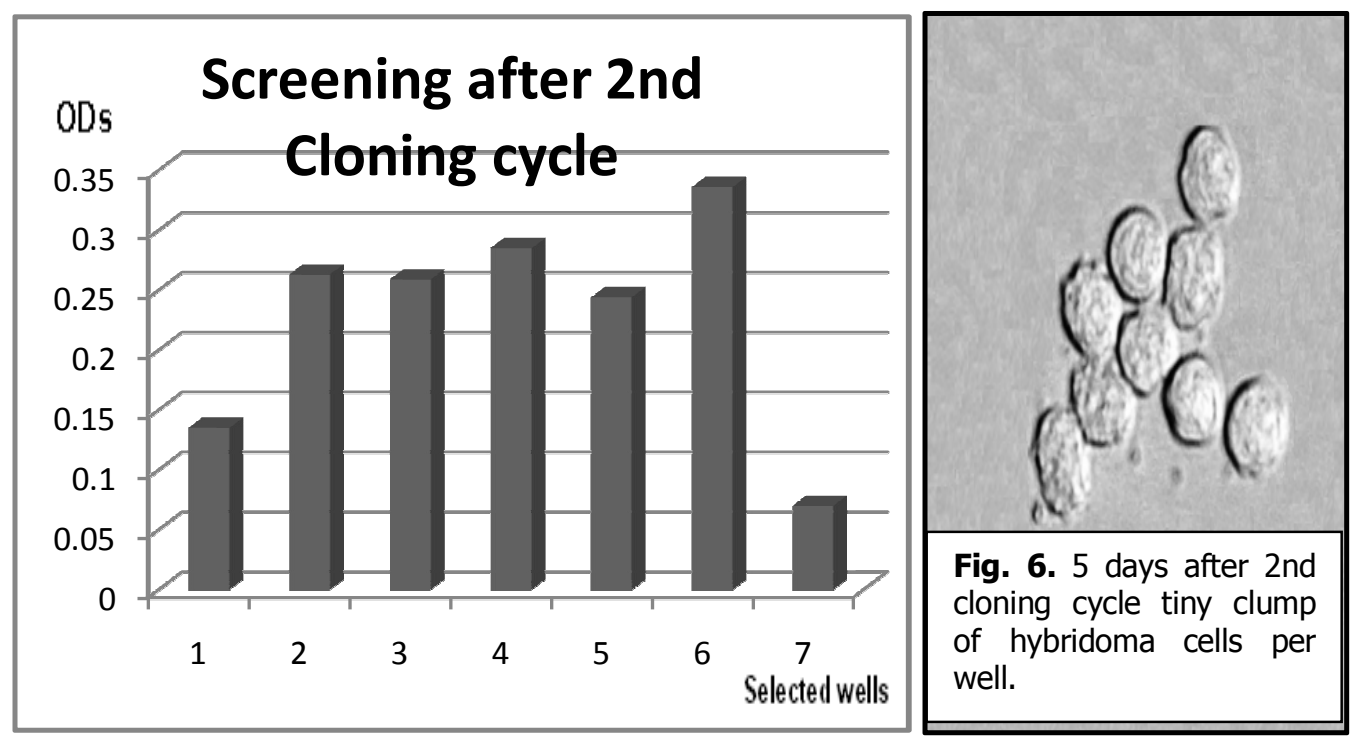

Fig. 5. Showing the selected 5 of 21 positive hybridoma clones that pass the $2^{\text {nd }}$ cloning round, (from 1 to 5 ) containing hybridomas secreting monoclonal antibodies against ILTV and all show higher ODs. ELISA signals than culture media (negative control 7) \& previously tested monoclonal antibodies against ILTV used as (positive control 6). 


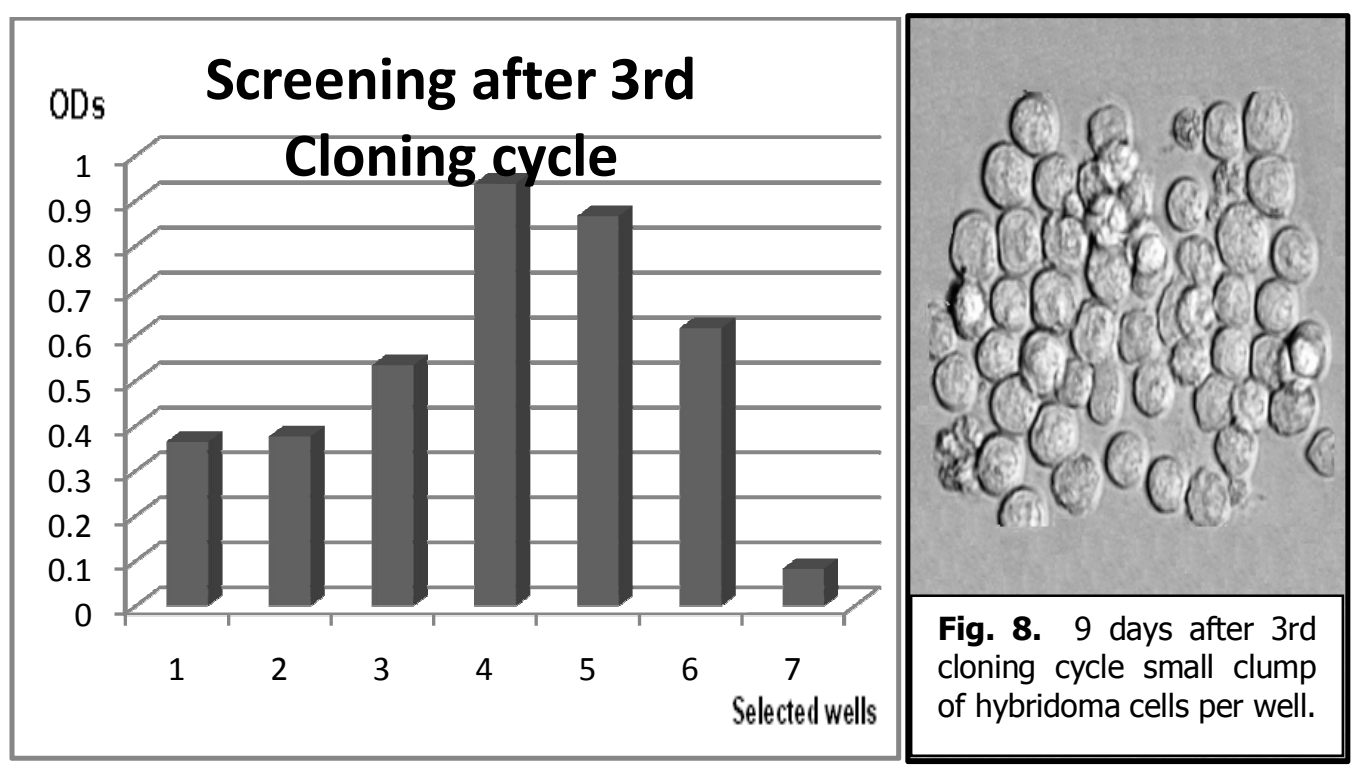

Fig.7. Showing the selected top 5 positive hybridoma clones after $3^{\text {rd }}$ cloning round (from 1 to 5 ) containing hybridomas secreting monoclonal antibodies against ILTV, all show higher ODs. ELISA signals than culture media (negative control 7).While previously tested monoclonal antibodies against ILTV used as (positive control 6). Notice that Mabs titers are 3, 5, 6, 8 and 9 folds higher than negative control after the $3^{\text {rd }}$ round of cloning.

Finally and collectively, 33 hybridomas secreted monoclonal antibodies specific for ILTV resulted from fusion and after limiting dilution cloning cycles of the 11 positive wells that selected after 1st screening. In the multiple cloning plates after fusion, 33 wells were selected containing hybridoma clones that survived the 2 weeks required for the cells to reach a sufficient population (50\% confluence) for ELISA assay. Collectively, 16 hybridomas from final plate1 and 17 hybridomas from final plate 2 were positive for monoclonal antibodies specific for ILTV. Three further rounds of cloning cycles were done for a 5 hybridoma clones of the selected 33 hybridomas to ensure monoclonality and stability of the cell line productivity. 


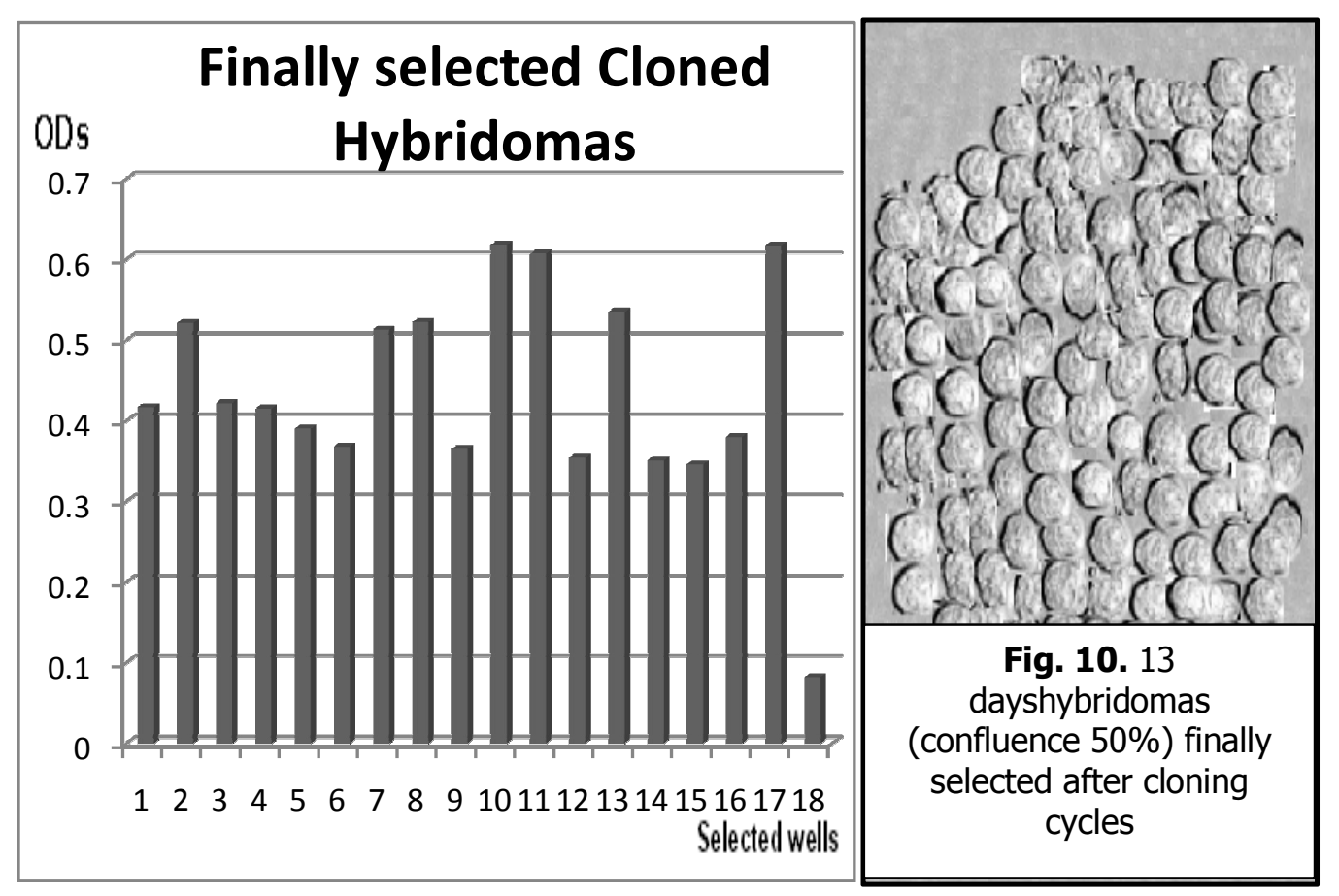

Fig. 9. Showing the other finally selected 17 hybridomas after cloning cycles to make the total of 33 hybridomas as a final result of our fusion, the 17 hybridomas showing strong growth with stable and specific monoclonal antibodies secretion against ILTV. All hybridomas show higher Positive ELISA ODs. Signals (from 1 to 17 ) in comparison with hybridoma culture media (negative control 18).

\section{DISCUSSION}

A Trial was made to prepare MAbs suitable for the diagnosis of ILTV by various tests and maintain the hybridomas in culture to continue to produce these MAbs for diagnostic and vaccine quality control purposes. Some hybridomas produced MAbs that had strong reactivity against all the ILTV antigen tested and proved specific for ILTV. Moreover, Thirty three hybridoma cell lines secreting MAbs against the ILTV were generated and identified with high affinity, stability, and specificity. These MAbs might be applied to develop specific diagnostic systems for ILTV infection and for vaccines evaluation.

Detection of ILTV antibodies in serum can be done through different tests: agar gel immunodiffusion (AGID), virus neutralization (VN) in ECE or cell culture, indirect fluorescent antibody (IFA) test, and ELISA. Actually, ELISA offers ease of testing for large number of sera. This method has been demonstrated to be more sensitive than VN (Bauer et. al., 1999). 
Enzyme-linked immunosorbent assay systems have been developed for detection and quantitation of ILTV-specific antibodies using purified whole virus as an antigen (Meulemans and Halen, 1982, York and Fahey, 1988).

After immunization of mice with purified ILT virus antigen, the humoral immune response to the immunizations was assessed by ELISA using purified ILTV as the target. The harvest of all cell fusions that were done during our work revealed that 11 positive wells containing hybridoma colonies were obtained and selected out of 288 wells from the three 96-well tissue culture plates of fusion by the initial ELISA screening for antibody production which used the purified ILTV as a coating antigen. Thirty three (33 cloned hybridomas) cell lines were produced that secreted antibodies specific for ILT virus. These cell lines were selected after cloning cycles based on the strong reaction of antibodies in their culture supernatants to ILT virus antigens as determined by ELISA and the absence of specific reaction when ELISA was done using uninfected CAM and culture supernatant. These established 33 hybridoma cell lines were secreting ILTV specific MAbs that shown to detect ILTV come in which matches with Bagust and Guy (1997).

Clones were isolated and their monoclonal antibody secretion was screened by indirect ELISA. Single cell cloning was performed to generate clonal lines. Singlecell clones were generated and specificity of the clones to ILTV was confirmed by ELISA screening against ILTV. Hybridomas producing monoclonal antibodies with strong ELISA reactivity signals against ILTV after cloning were identified. This ELISA was repeated multiple times during the cloning and recloning processes. Since production of monoclonal antibodies requires immortalization of splenocytes by somatic fusion to a myeloma cell line partner (hybridomas) and although hybridomas can be immortal, they may depend on a feeder cell layer and may be genetically unstable. Since the inception of hybridoma technology, efforts to improve efficiency and stability of monoclonal antibody-producing cell lines have not stopped . For that regard we further select 5 hybridomas from the finally selected 33 cloned hybridomas to pass extra 3 rounds of cloning in order to guarantee genetic stability and continuous production of monoclonal antibodies against ILTV.

In conclusion, we have successfully generated Mabs against ILTV. We screened the produced monoclonal antibodies against ILT virus. Five of the monoclonal antibodies recognized ILT vaccinal strain in an ELISA test. A limitation to our characterization of these monoclonal antibodies is that we have not yet identified the exact epitopes of these antibodies. Epitope mapping studies of these monoclonal antibodies is required to identify the exact epitope on ILT Virus. This suggests that 
those 5 monoclonal antibodies may recognize a common sharing epitope on ILT virus. Isotyping and characterization against ILTV proteins of our produced monoclonal antibodies is required for further scientific research studies against the nature of ILTV and also to help in the production of distinguishingly diagnostic kits that differentiate between recent and latent infection of ILTV in birds flocks.

\section{REFERENCES}

1. Abbas, F., J. R. Andreasen, R. J. Baker, D. E. Mattson, and J. S. Guy. 1996. Characterization of monoclonal antibodies against infectious laryngotracheitis virus. Avian Dis 40:49-55.

2. Anonymous. 1991. Current Protocols in Immunology. Green Publishing Associate and John Wiley and Sons, New York, USA. 2.5.1-2.5.17.

3. Bagust, T. J., and J. S. Guy. 1997. Laryngotracheitis. In: Diseases of Poultry, 10th ed. B. W. Calnek, H. J. Barnes, C. W. Beard, L. R. McDougald, and Y. M. Saif, eds. Iowa State University Press, Ames, IA. pp. 527-539.

4. Bauer, B., J. E. Lohr, and E. F. Kaleta. 1999. Comparison of commercial ELISA test kits from Australia and the USA with the serum neutralization test in cell culture for the detection of antibodies to the infectious laryngotracheitis virus of chickens. Avian Pathol 28:65-72.

5. Galfre. 0., S. C. Howe, C. Milstein, , G.W.Butcher, and I.C. Howard. 1977. Antibodies to major histocompatibility antigens produced by hybrid cell lines. Nature 266:550-552

6. Guy, J. S., H. J. Barnes, and L. G. Smith. 1992. Rapid diagnosis of infectious laryngotracheitis using a monoclonal antibody-based immunoperoxidase procedure. Avian Pathol. 21:77-86.

7. Hammerling, G. .1., U., Hammerling and J.F. Kearney. 1981. Monoclonal Antibodies and T-cell Hybridomas. Elsevier/ North- Holland Biomedical Press, Amsterdam, The Netherlands.

8. Izuchi, T., Hasegawa A. and MiyamotoI T. 1982. Studies ona live virus vaccine against infectious laryngotracheitis of chickens: I. Biological properties of attenuated strain C7. Avian Dis. 27(4): 918-926.

9. Johnson D. I., A .Vagnozzi, F. Dorea, S.M. Riblet, A, Mundt, G. Zavala , M. García. 2010. Protection against infectious laryngotracheitis by in ovo vaccination with commercially available viral vector recombinant vaccines. Avian Dis. Dec;54(4):1251-9. 
10.Kennett, R. H., T. J., McKearn, and K. B. , Bechtol. 1980. Monoclonal Antibodies, Hybridomas: A New Dimension in Biological Analyses. Plenum Press, New York.

11.Kohler, G., and C. Milstein. 1975. Continuous cultures of fused cells secreting antibody of predefined specificity. Nature 257:495-497.

12.Meulemans, G., and P. Halen. 1982. Enzyme-linked immunosorbent assay (ELISA) for detecting infectious laryngotracheitis viral antibodies in chicken serum. Avian Pathol 11:361-368.

13.Nowinski, R. C., M. E., Lostrom, M. R Tam,., M. R., Stone, and W. N. Burnette. 1979. The isolation of hybrid cell lines producing monoclonal antibodies against the p15(E) protein of ecotropic murine leukemia viruses. Virology 93:111-126.

14.Shan-Chia Ou and Joseph J Giambrone. 2012. Infectious laryngotracheitis virus in chickens. World J Virol. Oct.12; 1(5): 142-149.

15.Stoschek, C. M. 1990. Quantitation of protein. Methods Enzymol. 182:50-68.

16.York, J. J., and K. J. Fahey. 1988. Diagnosis of infectious laryngotracheitis using a monoclonal antibody ELISA. Avian Pathol. 17:173-182. 


\section{تحضير أجسام مناعية وحيدة الفسيلة مضادة لفيروس التهاب الحنجرة والقصبة الهوائية}

محمد محمود يوسف حنان محمد محمد الزاهدأمل السواح الهام عطا الابياري

$$
\text { المعهل المركزي للرقابة على المستحضرات الحيوية البيطرية }
$$

تم انتاج عدد ثلاثة وثلاثون خط من خلايا هيردوما التي تفرز أجسام مناعية مضادة وحيدة الفسيلة لفيروس التهاب الحنجرة و القصبة الهوائية (ILT). هذه الخلايا ناتجة عن التحام خلايا الميلوما P3X6-A98.653 مع خلايا الطحال لفئران البلبيسي و التي تم تحصينها من قبل بالعترة المنقاة لفيروس ILT ـ ثم تم قياس الاستجابة المناعية بعد التحصين بواسطة اختبار الاليز ا مستخدمين العترة المنقاة من فيروس ILT .و قد أجري فحص السائل السطحي بعد الالتحام الخلوي باستخدام اختبار

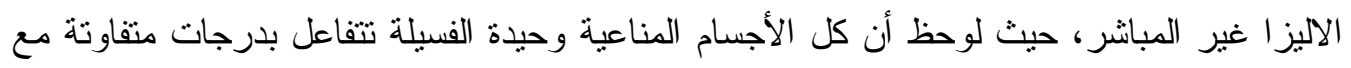
كل عنرات الفيروس سواء الفيروس المشتق من أجنة الكتاكيت أو الفيروس المشتق من الانسجة الخلوية.

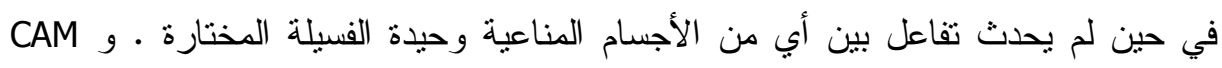
المأخوذة من بيض غير معدي بالفيروس. وقد دلت النتائج على أن الأجسام المناعية وحيدة الفسيلة

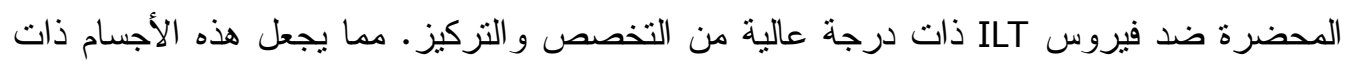

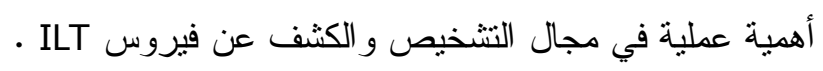

